\title{
INTERSECTION OF PERSONHOOD AND CULTURE: A NARRATIVE APPROACH OF PASTORAL CARE TO GENDER-BASED VIOLENCE ${ }^{1}$
}

\author{
John Klaasen \\ University of Western Cape
}

\begin{abstract}
What contribution does a narrative approach make to effective care for those affected by gender-based violence? Notwithstanding the contributions of feminist theologians who take experience and identity seriously (Ackermann and Ruether), open-ended narrative includes lived experience, embodied communication, and the identity of the victim as formative community as an effective approach of care. Experience as lived experience or actual reality is not what is interpreted by the dominance of those in the centre, but it is primarily the experience of the vulnerable at the margins. The post-structuralist critique of the structuralist approach to communication and difference and the other within a fluid community will be considered within the narrative approach of care. This article will also address the intersection between gender and culture. I will use Ackermann and Ruether's feminist lens as theological framework.
\end{abstract}

Key Words: Intersection; Personhood; Culture; Narrative; Pastoral Care; Gender Based Violence

\section{Gender and Violence}

Violence is defined by The World Health Organisation as: "The intentional use of physical force or power, threatened or actual, against oneself, another person, or against a group or community, that either results in or has a high likelihood of resulting in injury, death, psychological harm, maldevelopment or deprivation" (Krug et al., 2002:5). This is a comprehensive definition and includes the main phenomena such as the intentional misuse of power, the persons or groups affected, and the results of violence. Within this broad definition there are three kinds of violence, which are: self-directed violence, collective violence and interpersonal violence (Krug et al., 2002:6). This article will be restricted to interpersonal violence between a man and a woman, in the context of Gender-Based Violence (GBV).

Gender-based violence is an assertion of physical dominance between a man and woman and is characterised by physical, oppressive power that causes physical, psychological, or sexual harm. While men are also victims of gender-based violence, women are by far the most vulnerable to gender-based violence in the South African context. According to Peltzer, Mashego, and Mabeda (2003:150, 152), one in every eight South African women experience gender-based violence (Davies \& Dreyer, 2014:2).

While there are many causes of gender-based violence such as economic deprivation, social exclusion, psychological manipulation and religious structures, culture and personhood are two of the most common causes of gender-based violence within societies in

This article was delivered as a paper at The Society for Practical Theology in South Africa's annual conference 17-19 January 2018 in Pretoria. 
transition, such as South Africa. Who we are is formed by both selfhood and formation by practices within consistent environments over a long period. Within patriarchal and hierarchical societies men's self-understanding is intersected with dominant cultures.

Notions of who we are and cultural practices can contribute to gender-based violence. Religious and social understandings of what it means to be a person can be misconstrued as formations of individuals that develop within oppressive patriarchal and hierarchical systems.

Metaphors, symbols, language and instruments are used as tools of cultivation and interpretation for human behaviour within particular contexts (Louw, 2012:15). Weiss (2009:243) draws from Geertz and views culture as 'thick description' "of meanings towards understanding human social behaviour. According to this notion, cultures create symbols of values, which express meaning of human behaviour. Human behaviour can only be understood in the context of the respective social and cultural interpretation patterns...". Culture is the context of human behaviour and the means of meaning making and interpretation of behaviour. Culture is integrally connected to identity in a way that personhood is connected to the Imago Dei. Lartey (2003:31) adds to the connection between behaviour and identity by asserting that culture is embodied in structures. He concludes that culture "has to do with the way in which patterns of life in a group are structured with an emphasis on how these structures are experienced, understood and interpreted. These structures and their meanings influence the on-going collective experience of groups" (Lartey, 2003:31). Patriarchal and hierarchical structures result in separation and domination, which has been responsible for the construction of gender stereotypes and for many theologians who work within a liberation paradigm, maledominated gender construction is the principle cause of gender-based violence.

Care for victims of Gender-Based Volence is most effective when personhood and culture intersect within the context of the narratives of the victims. Drawing from the approaches of Ackermann and Ruether, I seek to explore how narratives of victims of gender-based violence can provide effective care for both victims and perpetrators.

\section{What is Effective Care for those affected by Gender-Based Violence}

Pastoral care is widely accepted as a combination of the meaning of the term pastoral, "tending to the needs of the vulnerable", and care as "the attentive concern for the other" (McClure 2012:269). 'Vulnerable' does not refer to the weak or subordinate, but the condition that certain persons find themselves in over above other persons. Vulnerability is not an absolute condition, but rather the result of social, political, religious, scientific and cultural practices. Although women are vulnerable because of conditions beyond their control, such as wars and sickness and the inevitability of death, gender-based violence is not justifiable and is not positive vulnerability. However, centuries of hierarchy and patriarchy in all facets of the identity of women and men, has made negative vulnearbility normative for women. O'Donnell Gandolfo rightly claims that women are vulnerable throughout their lifespan. From the uncontrollable health risks during pregnancy and childbirth such as haemorrhage, infections, and obstructed labour to obstetric fistula post-child-birth.

The reason that our bodies are so vulnerable is that part of the nature of embodiment is receptivity. Nobody is an island. All bodies - and here I include molecular, chemical, cellular, biological, animal and human bodies - are naturally and necessarily receptive to other bodies in some way, shape or form. This means that all bodies are affected by their interactions with other bodies (either positively or negatively) and this makes all bodies vulnerable to harm or even destruction by other bodies (O’Donnell Gandolfo, 2015:39-45). 
Does this mean that if the conditions are changed, negative vulnerability will disappear? Du Plessis (2015:2) asserts: "Although certain groups are vulnerable because of their social status (e.g. women and children), an individual's vulnerability is determined by the situation". Vulnerability is closely associated and even determined by external factors beyond the control of victims of gender-based violence.

Koopman's notion of vulnerability is rooted in Trinitarian anthropology. He asserts that "vulnerability also enhances a human rights culture" (2003:203). Like Du Plessis, he also refers to the disempowering of the vulnerable. Using the Protestant confession of justification by grace, Koopman asserts that to receive is more important than to give (2003:204). Koopman does not address the power relations and thus, places his assertion within the power imbalance between the centre and the margins. Within the context of gender-based violence, the victim (woman) remains powerless and at the mercy of the powerful, whether that is a professional pastoral carer or the perpetrator of violence. The question about the position of the victim in relation to the perpetrator in not fully addressed. How is the power relations between victim and perpetrator addressed?

A narrative approach to gender-based violence explores women as the other, but not as the less significant one or the absolutely dependent one. The other is not the different one who is excluded by constructed boundaries of unequal power relations. The other is not seen through the lenses of elimination, assimilation (Miroslav Volf), dominance and abandonment (Ackermann 2000:110). The other has meaning for self and is meaning making. Women are not powerless or insignificant within the process of pastoral care. They are not only victims but they have certain experience and skills that contribute to healing. Women should occupy the space that causes transformation and they should not be eliminated or marginalised in the process. They have worth and give worth.

Within this meaning of pastoral care, there is a particular, but not exclusive, concern for the victim of gender-based violence, who is usually the woman. The care is not an allknowing approach by the pastoral carer or one of the professional versus the client, but the other becomes the one who deconstructs and constructs. This article explores women as indispensable partners in pastoral care. The one who causes the violence is disempowered and the pastoral carer(s) depends on the women for effective pastoral care.

\section{Ackermann and the Struggle for Common Humanity}

Ackermann, one of South Africa's foremost feminist theologians, applies "healing as a theological praxis" within the South African context, where "violence is an endemic reality in our society" (2000:102-103). Ackermann approaches violence from the perspective of the politics of violence and clearly connects identity with violence by highlighting that violence is identified with the victim, with who commits the violence and who has the power. Ackermann differs from Louw, Weiss, and Lartey, and warns against the assumption that violence is behaviourist. She gives greater attention to "agency" or "decision" than circumstances. "The question of agency, of choice, is extremely important in the search for an appropriate theological and pastoral response to violence" (2000:105-106).

Ackermann's assertion for greater attention to the transformation of the self than a change in circumstances is a plausible assumption: while change in circumstances influences behaviour, it does not necessarily empower the other within the context of gender-based violence. It is for this reason that her approach to healing praxis is directed towards the healing of creation and search for common humanity. A search for a healed creation by healing praxis takes seriously both "those who are suffering, marginalized and oppressed as well as those who have privilege and power, provided they too understand its 
genesis in the hope for a restored creation, and are willing to hear the pain of the suffering of 'the other' and to act in response" (Ackermann, 2000:107).

Boundaries and difference are important aspects of the identity. Boundaries can be both positive and negative. Within a changing social context such as South Africa, boundaries help to embed identity in historical critical contexts. Ackermann affirms boundaries as helpful for the development and forming of the "unique self of every person" (2000:111). Boundaries protect the self and provide meaning-making of the self. This is in line with Ackermann's assertion of the importance of choice in acts of violence. However, Ackermann does warn against the potential of exclusion by drawing boundaries. Boundaries must be inviting, dialogical, and conversational, otherwise they become tools of psychological mal-development and physical violence.

Difference can also lead to exclusion. Within the Christian tradition, the biological difference between the two persons in the creation story, Adam and Eve, has been used to substantiate gender oppression under the label of "complementarity" or "distinctiveness". Different sexes imply complimentary fixed roles. Within the institutional churches, patriarchy has entrenched these kinds of notions of identity. Modernism with its grand narratives and universalism can also cause the self to disintegrate in the quest for commonality. Ackermann claims that "differences are always in relation" (2000:111).

Ackermann's feminist theology of healing praxis approach has seven markers. "The act of lament is one of self-expression which re-establishes communication". Narratives evoke memory and draw the perpetrators of violence into the process of care. Embodied practical theology implies that reality is conveyed through bodies. "Theology is also about imagination that is characterised by willingness and beyond ... We are agents of God's creation and lastly we must practice vulnerability" (2000:112-117).

Ackermann raises important tensions that are typical in postmodernism. How does the self relate to other(s) in a meaningful, mutually enriching relationship, difference and identity and bodies and reason? Within these broad tensions there is also the ambiguity of imagination, boundaries and communication. Amidst the uncertainty is the constant of our common humanity. Violence has the potential to disguise the divine creation, which is the Imago Dei. A feminist theology of healing praxis seeks to restore the sacredness of the other for the discovering of the unique person. It is the calling of both women and men to transcend the violent culture prevalent in South Africa and embedded in patriarchy and hierarchy.

\section{Ruether's and the Dialectical Methodology}

Like Ackermann and most other feminist theologians, Ruether's methodology and approach is based on experience as key in the hermeneutical process. For Ruether (1983), women's experience within patriarchy and hierarchy and not experience in general, forms the concrete starting point of the dialectical approach. The violence as a result of patriarchy and exclusion of women from the centre is the reality that forms the context for women's emancipation. However, Ruether's use of women's experience is not limited and is placed within the human experience. "Human experience is the starting point and the ending point of the hermeneutical circle" (Ruether, 1983:12).

Ruether's feminist theology is also about the full humanity of women. Ackermann (2008:37-46) rightly asserts that Ruether's vision is inclusive and that this "does not divert her from what she considers the critical principle of feminist theology - the promotion of the full humanity of women". In Sexism and God-Talk, Ruether unveils the primary principle of her approach of feminist theology as "the promotion of the full humanity of women. Whatever denies, diminishes, or distorts the full humanity of women is, therefore, 
appraised as not redemptive. Theologically speaking, whatever diminishes or denies the full humanity of women must be presumed not to reflect the divine or an authentic relation to the divine" (Ruether, 1983:18-19). The primary principle is symptomatic of the dialectical methodology that Ruether applies throughout her feminist theology. Instead of a dualism of women's experience of marginalisation and degradation and the transcendence of such evil, a dialectical approach places the concrete experience in a much broader and often repressed experience. The end goal is the promotion of women's humanity (Jamieson, 2013:5).

Snyder (1988:15) asserts that Ruether "has constructed a methodology that is dialectical, one that she believes does justice to her search for truths that will set us all free". Dualisms, like man/woman, provides either-or that is disconnected. Dialectics, on the other hand, transcend polarities to form synthesis for transformation or conversion. GenderBased Violence is a result of dualistic categorisation that causes hierarchy of power and false identities. Through historical analysis and deconstruction, Ruether uncovers the root of injustice (Jamieson, 2013:6). "Dialectical thinking for Ruether provides a way to discover deeper truths about persons, communities, and ideas that may appear on the surface to be oppositional or negative, but ... after their polarities are explored in a mutually critical way, reveal new insights and syntheses heretofore unrealized" (Snyder, 1996:399-410).

Historical analysis and deconstruction as assumptions of dialectics provide an openness and critical engagement that invites opposites with the intentionality of newness. Like Ackermann, Ruether seeks to transcend the concrete experience of violence towards healing and justice. Unlike Ackermann, Ruether uses the distorted humanity as a means toward unravelling the layers of disguise. These disguises can come in the form of NeoPlatonic influence on Augustine's view that the soul has two functions, of which both are different for women and men, the Greek and Latin Church fathers' view that feminine symbols reflects the "lower passions and bodily nature, and the masculine ... symbolize the higher rational and spiritual nature", ${ }^{2}$ and Thomas Aquinas, who claims that women are not only inferior by virtue of the divine law, but also by their physical and biological defectiveness and the hierarchical nature of man and woman as part of Luther's ecclesiology (Klaasen, 2016). ${ }^{3}$

Ruether starts with the experience of women in contexts of oppression and moves "backwards" to uncover what has been covered over. The dialectical approach uses mechanisms such as historical analysis of God/dess and the authentic self as the broader context of gender violence. "Authenticity refers to a willingness and a capacity to be grounded in our existence. God/dess is the ground of all being, the matrix of existence. God/dess can be compared to a womb from which all life was shaped and came into existence. In being authentic, the human person aligns himself or herself to that ground and matrix of all being" (Jamieson, 2013:25).

\section{Ackermann and Ruether and the Quest for a Narrative of Care}

Both Ackermann and Ruether, like feminist liberation theologians such as Carol Gilligan, Rebecca Chopp and Miranda Pillay, use experience and liberation as their primary principle of their methodologies. Ruether uses the specific women's experience and women's humanity, while Ackermann uses the human experience and common humanity (Klaasen,

2 Rosemary Radford Ruether, "Sexism and Misogyny in the Christian tradition: Liberating alternatives", Buddhist-Christian Studies 34, 2014:83-94.

3 For a more detailed discussion see Klaasen, 2016. 
2016:8-12). Both theologians seek to transcend the present reality and seek the authenticity of humanity beyond the distorted notion of the image of God. While Ruether attempts to dialogue with the past/history in order to synthesise the perceived dualisms that divide for separation and domination, Ackermann seeks solution in the present analysis of identity, differences and commonalities. Ackermann suggests "markers", which can be related in a process or system but do not necessarily follow a systematic set of stages. Both Ruether and Ackermann acknowledge the role of culture and what it means to be human, in care and emancipation of victims of violence. Ackermann opts for choice as a determining factor of violence over circumstances which gives culture a lesser role in care than Ruether's historical analysis and critique of social constructionism. This is evident in Ruether's move from the natural paradigm of feminist theology to the social constructionist paradigm (Klaasen, 2016:2-4).

The following can be identified as limitations of Ruether's approach: while Ruether understands the limited options of women in the present patriarchal society and subsequent violence, she does not develop why this is the case. Secondly, she does not identify any emancipatory tools for women in patriarchal societies (Jamieson, 2013:32-33). Ackermann, on the other hand, does not seek to change the circumstances (culture), but change the agency (personhood) from alienation and domination to a common humanity. She does not go far enough to relate the culture (circumstances) with who we are. Violence against women is more a matter of choice than structure.

Narrative approaches have become important in practical theology in the last two decades. The use of narrative in pastoral care can be associated with Charles Gerkin, Chris Schlauch, Andrew Lester, and Julian Muller (Ganzevoort, 2012:218-219). Within the South African context, Ackermann has drawn on the narrative approach, although she has not identified herself as a narrative practical theologian. In her model of feminist theology, a feminist theology of praxis, Ackermann does not use narrative as an approach of feminist theology, but as identity, including agency. She moves from agency as choice (2000) to agency as activity (2006). Ackermann draws on the use of praxis by Rebecca Chopp (1996) (former student of Ruether) as social activity (2003:225-232).

Müller is the foremost narrative practical theologian in South Africa. Müller (2015:33) "strongly argues for the not knowing position of the narrative approach as the only acceptable approach in an intercultural therapeutic situation" 4 . This approach is characterised by "mutual conversational co-creation of new stories", "historically situated interchanges between people", understanding on the basis of "vicissitudes of social processes", and "negotiated understanding" (2015:34). Influenced by Wentzel van Huyssteen's postfoundational theology, Müller develops a post-foundationalism approach ${ }^{5}$ of practical theology.

Like most narrative practical theologians, Müller's approach neglects the marginalised groups and those at the periphery, who use narrative as "an audience to tell their stories". This is also commonly neglected within practical theology (Ganzevoort, 2012:214). Marginalised groups find the centre space in the feminist and womanist theology (Carol Christ), liberation theology (Gustaff Gutierrez), and black theology (James Cone).

\footnotetext{
This article was first presented as a paper at the $10^{\text {th }}$ International Seminar on Intercultural Pastoral Care and Counselling, 1996, in Ustron, Poland and published in Intercultural Pastoral Care and Counselling, 2 1997, 408.

5 Sung Kyu Park, a former student of Julian Muller, provides an interesting discussion of social-constructionism and post-foundationalism in Park, S-K., 2010, 'A postfoundationalist research paradigm of practical theology' HTS Teologiese Studies/Theological Studies 66(2), Art.\#849, 6 pages.
} 
My own use of narrative is an attempt to provide an intersection between personhood and culture for effective care. Care cannot be effective within the division of culture and who we are. Personhood is social and not independent, unconnected, and separate, but culture and personhood intersect within the space of narrative. There is an overlap between culture (the structural long-term practices that influence behaviour) and personhood (who we are in form and forming).

I do not refer to narrative as a closed system disconnected through differences and ambiguities, but as transcendence of violence caused by separation, domination, alienation, abandonment and assimilation. Narrative reinterprets boundaries as points of contention and pointers to newness. Narrative is referred to as open-ended. It is inductive and consists of communication (telling the story), experience (living the story) and community (being the story). These three, telling the story, living the story and being the story, are three interactionist episodes of the narrative.

\section{Embedded Communication}

Communication cannot be restricted to written words or disembodied meaning-making. Language has meaning in context and the invisible surroundings are as important as the visible written communication. Communication is meaningful through the presence of other(s). Jeeves (2011:306) asserts that "Schleiermacher realizes, as did Wittgenstein, that were Adam alone in the garden he would not only be unable to reproduce, he would be unable to speak. Speech is a pre-eminently social possession. And without speech there would be no praise, no prayer, no 'world'.

Communication in the context of narrative is not an isolated reality like abstract reason by an autonomous individual. Although pastoral care has moved beyond the single discipline approach (influenced by Boisen's writings), the critical reflection on experience approach of Hiltner and James's empirical theology and experience and function (Patton, 2000:51), embodied communication gives a greater focus on the redemptive nature of the telling of the story beyond the text by the victim. Communicating narrative is reciprocal and invites the hearer to listen with the acknowledgement that response and actions are invitations.

Gestures, symbols and body language should be taken seriously, both as a means and an end. It is not only the medium of the narrative but part of the essence of the narrative. What lies between the written text or at the margins forms part of the meaning of the text: "This means a text is never stable or fixed, but always open to endless interpretation and reinterpretation that stretches to a receding horizon within which meaning is endlessly deferred. This combination of what is not said, but which echoes around the text, and deferral of meaning, is termed differance by Derrida" (Goodlief, 1998:44). "Difference" means pushing the boundaries of the text to suspended meaning. Post-structualists are quick to make the point that "difference" does not refer to differences in substance or function, but an extension of meaning. There is greater openness to interpretation than the limitation of meaning of the disembodied text.

Communication evokes memory and interprets the present through the past. Like Ackermann's reference to the stories of the Truth and Reconciliation, which is both the foundation for truth and what is real, the boundaries for moving beyond and Ruether's search for the repressed reality in history, embodied communication provides the space for broader interaction and effective healing. Interpersonal violence is unmasked as physical scars, but the lifetime consequences of emotional and psychological trauma of subjugation, inferiority, and alienation are also communicated as being in need of healing. 


\section{Lived Experience}

Both Ackermann (2008) (human experience) and Ruether (1983) (experience of women) affirm that experience is part of the fundamental principles of their approaches of feminist theology. Within practical theology and in pastoral care, experience has drawn new attention within postmodernism and the critique against meta-narratives, universalism, autonomous individuality and abstract reason. While postmodern social and theological notions can be criticised for replacing the absoluteness of universalism and abstract reason with particularity and non-rationality, there has been an upsurge of critical engagement of the relationship between theory and practice.

In her article The Theory-practice Distinction and the Complexity of Practical Theology (2016:1-8), Miller-McLemore provides a provocative analysis of the relationship between theory and practice. She surveys Tracy's $(1998 ; 2011)$ inevitable distinction between theory and practice and the dialectical relational approaches of Forrester (1999), Mikoski (2014), Heitink (1999), Browning (1999), Mercer (2014) and Burrows (1995) (2016:1). MillerMcLemore recognises the complexity of separating theory and practice and the oversimplification of the relationship by many pastoral care practitioners and theologians. Her own idea lies in the question: What kind of knowledge? She appreciates both theoretical knowledge and practical knowledge as terrains for practical theologians. She opts for practical knowledge, which values theory as knowledge that develops within praxis such as violence, through observation of such circumstances. Theory also needs interpretation to appeal to a wide range of audiences and changed perceptions and understandings. Theory has limitations. "Practice escapes or surpasses theory in everyday life in two important ways: it eludes theory and trumps theory" (2016:5-6). Miller-McLemore ends her article by emphasising the importance of practice in practical theology and pastoral theology with some measure of ambiguity, but what seems to be a major step towards the advancement of the debate of theory versus practice. She concludes: "There is, in short, a need for more analysis of how theory and practice function dynamically in practice and for fresh appreciation for the complications of their pragmatic relationship" (2016:7).

Without underestimating the complexity of practice and theory, a narrative approach of pastoral care for victims of gender-based violence opts for the experience of the victim to be prioritised for the immediacy of the need. The experience is the reality of the victim and those who identify with the victim are drawn in as fellow-participants in the story. The victim does not relate to general human experience, but lived experiences, which are first personal and then communal. Lived experience is the actual experience that is narrated as reliving the extent of the transgressions and their effects.

The pastoral carer (the professional pastor or group carer) plays a role in healing only as far as they can put their skills within and alongside the actual experience of the victim. The pastoral carer loses the all-powerful and all-knowing status to the more comprehensive telling of the story from the margins. The experiences of the victim draw the pastoral carer into the authenticity of the need for the healing of creation. Knowledge becomes a matter of what kind of knowledge instead of abstract reason. Knowledge is produced by experience, not in the way that Ackermann seeks to keep doing (ethical) and knowing (theology) in a tension that forms a dualism with knowledge as primary within her feminist theology of praxis (2003:227). Within an open-ended narrative approach, lived experience (living the narrative) and not technical knowledge of modernity interacts with embedded communication and humanity in community for effective pastoral care.

Lived experience produces knowledge. When knowledge is embedded in the story, the lived experience is what is needed to make sense of gender-based violence. Knowledge is 
not restricted to the abstract knowledge of the professional or the practical knowledge (Browning 1999; Miller-Mclemore 2016) of the practitioner, but the meaning of actual experience as relived by the victim.

Effective pastoral care stems from listening with flexibility and creativity. The former refers to an openness to the process and the latter to transcending the limitations of the experience. The barriers of experience are pushed to the edge where limitations are challenged as moments of care.

\section{Humanity in Community}

Whose story? The skilled professional pastoral carer (cleric) or skilled pastoral care groups (lay councillors and psychologists) usually take centre stage in pastoral care. Skills determines the nature and direction of the care. Within a narrative approach, the person is the nature and direction of care. The person is the narrative and is both the care receiver and care giver. The person (care receiver and caregiver) is not an isolated, absolutely independent individual, but as Ackermann asserts, she shares a common humanity. The person is in an (inter-) dependent vulnerable relationship with the other(s) within the context of pastoral care.

The community that narrative depicts is not made up of isolated individuals who form a collective for the purpose of commonality. This kind of community does not exist out of the authenticity of community, but rather out of necessity for the purpose. When the purpose has been achieved, the community disintegrates. A narrative approach to pastoral care assumes that community is the essence of personhood. Louw asserts: "The basic presupposition is that the manner in which we view human beings will determine how we treat human beings. One can argue that anthropology provides the paradigms ... that determine the attitudes of people (habitus) and their position within the realm of human relationships" (2012:4).

Lartey makes the claim that human beings are fully understood within the complex interaction between culture, individuality, and human characteristics. He uses the noun 'other' to draw the continuum amongst the three, despite some definite particularities. With regard to culture, he means that "we are like others" in the sense of valuing the world through worldviews, values, prejudices, frames of references, language, and customs. The individual, like no other, refers to personal characteristics like fingerprints and dental parts that are unique to each person. Human characteristics refer to such phenomena as physiological, psychological and cognitive abilities, which are part of all human beings (2003:171-172).

Pastoral care always takes place within the context of community. The starting point is the story, the person who is both the receiver and giver of care. The story of the abused person provides the "stage" and the narrator. The story is not closed, but open-ended and invites the audience to participate in the different episodes. Cochrane (2009:16-17) describes this kind of interaction as the imago Dei within the Christian narrative. It is logically analysed as the figured but not yet exhausted (logos) and the prefigured but not captured (myth), and is part of the Christian understanding of what it means to be created in God's image. The cared for and the caregiver (including others who care) are not separate isolated individuals, but interdependent vulnerable persons in community. Cochrane refers to the "slippage in the self between consciousness and the unconscious and ... the equally pertinent slippage in the relationship of the self to the other" (2009:16-17). The Christian narrative provides the space for the care giver and care receiver to confront their own identities in view of the identity of the constructive other, and ultimately in relation to the 
Trinity. The Christian narrative embodies the narrative of Jesus Christ, the Holy Spirit, and the Father, and draws persons into community forming and personal growth and healing.

\section{Conclusion}

Feminist theologians such as Ackermann and Ruether have used experience as hermeneutical key for the analysis of women's gender construction by hierarchical and patriarchal systems and processes. These constructions cause notions of personhood and cultural practices that form the foundation of Gender-Based Violence. Changing situations or constructions based on dialectics do not necessarily result in healing. An open-ended narrative approach with the three interactionist movements of lived experience, embodied communication, and humanity in community takes the story of the victim as meaningmaking and space for pastoral care. The lived experience of the victim is the power of the margins and not the dominance of the centre. The experience of the vulnerable is not placed within a hierarchy of socially constructed gender isolated humanity; within the Christian story, experience is aligned with the redeeming suffering of Jesus Christ. Communication is not disembodied words or language whose meaning has been constructed by maledominated traditions. The post-structuralist use of language as both the written and oral, visible and invisible, gestures, symbols and metaphors, all form part of the meaning of what is communicated. The victim (the woman) does not receive, but gives meaning to the authenticity of pastoral care. The victim also invites the other participants to become part of the healing process. This happens within a fluid community where barriers and boundaries become points of potential transcendence and healing, rather than spaces of exclusion, domination, elimination and abandonment.

\section{BIBLIOGRAPHY}

Ackermann, D 2000. From Violence to Healing, in IT Douglas and K Pui-lan (eds.). Beyond Colonial Anglicanism; The Anglican Communion in the Twenty-first Century. New York: Church Publishing Incorporated.

Ackermann, D 2006. 'From mere Existence to tenacious Endurance', in IA Phiri \& S Nadar (eds.). African Women, Religion, and Health: Essays in Honour of Mercy Amba Ewudzima Oduyoye. Pietermaritzburg: Cluster Publications.

Ackermann, D 2008. "Rosemary Radford Ruether: Themes from a Feminist Liberation Story". Scriptura 37:46.

Cochrane, JC 2009. On Identity and Faith in the Global Political Economy'. Journal of Theology for Southern Africa 134:14-31.

Davies, PJ \& Dreyer Y 2014. 'A Pastoral Psychological Approach to Domestic Violence in South Africa'. HTS Teologiese Studies/Theological Studies 70(3), Art. \#2802, 8 pages.

Du Plessis, AL 2015. 'Principles for the Pastoral Guidance Process to Women on Matters related to Human Vulnerability and Personal Integrity'. HTS Teologiese Studies/Theological Studies 71(2), Art.\#2068, 6 pages.

Goodlief, P 1998. Care in a Confused Climate: Pastoral Care and Postmodern Culture. London: Darton, Longman and Todd Ltd. 
Personhood and Culture: A narrative Approach of Pastoral Care to Gender-Based Violence 11

Jamieson, C 2013. Christian Ethics and the Crisis of Gender Violence: Exploring

Kristeva's Reading of Religion, Culture and the Human Psyche. New Delhi:

Christian World Imprints.

Jeeves, M (ed.) 2011. Rethinking Human Nature: A Multidisciplinary Approach. Grand

Rapids, Michigan: William B Eerdmans Publishing Company.

Koopman, N 2003. Trinitarian Anthropology, Ubuntu and Human Rights, in K Sporre and

R Botman (eds.). Building a Human Rights Culture: South African and Swedish

Perspectives. Falun: Stralins.

Krug G, Dahlberg LL, Mercy JA, Zwi AB \& Lozano R (eds.) 2002. World Report on

Violence and Health. Geneva: World Health Organization.

Lartey, EY 2003. In living Color: An Intercultural Approach to Pastoral Care and

Counselling. Jessica Kingsley Publishers, London.

McClure, B 2012. Pastoral Care, in Miller-McLemore, BJ (ed.). The Wiley-Blackwell

Companion to Practical Theology, pp 169-278. West Sussex: Wiley-Blackwell

Publishing Ltd.

Miller-McLemore, B 2016. 'The Theory-practice Distinction and the Complexity of

Practical Knowledge'. HTS Teologiese Studies/Theological Studies 72(4),

a3381.http://dx.doi.org/10.4102/hts.v72i4.3381.

Muller, J 2004. 'HIV/AIDS, Narrative Practical Theology, and Postfoundationalism: The Emergence of a New Story', HTS Teologiese Studies/Theological Studies 60(1\&2).

Muller, JC 2011. 'Postfoundational Practical Theology for the Time of Transition'. HTS Theological Studies 67 (1), 1-5.

Muller, J 2015. 'Intercultural Exchange: A Discovery of Being Different', in K Federschmidt \& D Louw (eds.). Intercultural and Interreligious Pastoral CareGiving, pp. 27-36. Norderstedt: Books on Demand.

O' Donnell Gandolfo, E 2015. The Power and Vulnerability of Love: A Theological Anthropology. Minneapolis: Fortress Press.

Park, SK 2010. 'A Postfoundationalist Research Paradigm of Practical Theology'. HTS Teologiese Studies/Theological Studies 66(2), Art.\#849, 6 pages.

Patton, J 2000 'Introduction to Modern Pastoral Theology in the United States', in

J Woodward and S. Pattison (eds.). The Blackwell Reader in Pastoral and Practical Theology, pp. 49-58. Oxford: Blackwell Publishers.

Radford Ruether, R 1983. Sexism and God-Talk: Toward a Feminist Theology. Londn: SCM Press.

Radford Ruether, R 2014. "Sexism and Misogyny in the Christian Tradition: Liberating Alternatives". Buddhist-Christian Studies 34:83-94.

Snyder, MH 1996. "Rosemary Radford Ruether" in DW Musser \& JL Price (eds.). A Handbook of Christian Theologians. Nashville: Abingdon Press.

Snyder, MH 1988. The Christology of Rosemary Radford Ruether: A Critical Introduction. Connecticut: Twenty-third Publications.

Weiss, H 2009. 'Interreligious and Intercultural Pastoral Care and Counselling: Notes from a German Perspective', in DN Schipani \& LD Bueckert (eds.). Interfaith Spiritual Care: Understandings and Practices, pp. 235-258. Ontario: Pandora Press. 